\title{
First glycoside hydrolase family 2 enzymes from Thermus antranikianii and Thermus brockianus with $\beta$-glucosidase activity
}

\author{
Carola Schröder ${ }^{\dagger}$, Saskia Blank ${ }^{\dagger}$ and Garabed Antranikian* \\ Institute of Technical Microbiology, Hamburg University of Technology, Hamburg, Germany
}

Two glycoside hydrolase encoding genes (tagh2 and tbgh2) were identified from different Thermus species using functional screening. Based on amino acid similarities, the enzymes were predicted to belong to glycoside hydrolase $(\mathrm{GH})$ family 2. Surprisingly,

\section{OPEN ACCESS}

Edited by:

Noha M. Mesbah,

Suez Canal University, Egypt

Reviewed by:

Yasser Gaber,

Beni-Suef University, Egypt

Satyanarayana Tulasi,

University of Delhi, India

*Correspondence:

Garabed Antranikian,

Institute of Technical Microbiology, Hamburg University of Technology, Kasernenstr. 12, Hamburg D-21073,

Germany

antranikian@tuhh.de

${ }^{\dagger}$ Carola Schröder and Saskia Blank have contributed equally to this work.

Specialty section: This article was submitted to Process and Industrial Biotechnology, a section of the journal Frontiers in Bioengineering and Biotechnology

Received: 09 March 2015 Accepted: 10 May 2015

Published: 03 June 2015

Citation:

Schröder C, Blank S and Antranikian G (2015) First glycoside hydrolase family 2 enzymes from

Thermus antranikianii and Thermus brockianus with $\beta$-glucosidase activity.

Front. Bioeng. Biotechnol. 3:76. doi: 10.3389/fbioe.2015.00076 both enzymes (TaGH2 and TbGH2) showed twofold higher activities for the hydrolysis of nitrophenol-linked $\beta$-D-glucopyranoside than of -galactopyranoside. Specific activities of $3,966 \mathrm{U} / \mathrm{mg}$ for $\mathrm{TaGH} 2$ and $660 \mathrm{U} / \mathrm{mg}$ for $\mathrm{TbGH} 2$ were observed. In accordance, $K_{m}$ values for both enzymes were significantly lower when $\beta$-D-glucopyranoside was used as substrate. Furthermore, TaGH2 was able to hydrolyze cellobiose. TaGH2 and $\mathrm{TbGH} 2$ exhibited highest activity at 95 and $90^{\circ} \mathrm{C}$ at pH 6.5. Both enzymes were extremely thermostable and showed thermal activation up to $250 \%$ relative activity at temperatures of 50 and $60^{\circ} \mathrm{C}$. Especially, $\mathrm{TaGH} 2$ displayed high tolerance toward numerous metal ions $\left(\mathrm{Cu}^{2+}, \mathrm{Co}^{2+}, \mathrm{Zn}^{2+}\right)$, which are known as glycoside hydrolase inhibitors. In this study, the first thermoactive GH family 2 enzymes with $\beta$-glucosidase activity have been identified and characterized. The hydrolysis of cellobiose is a unique property of TaGH2 when compared to other enzymes of GH family 2. Our work contributes to a broader knowledge of substrate specificities in GH family 2.

Keywords: $\beta$-glucosidase, glycoside hydrolase, thermostable, Thermus antranikianii, Thermus brockianus, cellobiose, truncated domains

\section{Introduction}

Glycoside hydrolases (GHs) (EC 3.2.1.X) hydrolyze glycosidic bonds between carbohydrates or between carbohydrate and non-carbohydrate components, for instance alcohols or phenols. To date, enzyme classification is based on amino acid similarities rather than substrate specificity (Henrissat, 1991). GHs are assigned to different groups based on conserved domains, and the families are numbered from 1 to 131 that are listed in the Carbohydrate-Active Enzymes Database ${ }^{1}$ (Lombard et al., 2014). Evolutionary or structurally unrelated $\beta$-glucosidases (EC 3.2.1.21) are found in six GH families $(1,3,5,9,30$, and 116). The majority of identified $\beta$-glucosidases is grouped in GH family 1 (Cairns and Esen, 2010). $\beta$-Galactosidase activity can be found in different $\mathrm{GH}$ families $(1,2,3,16,20,35,42,43,50$, and 59$)$. In contrast to GH family 1 , no $\beta$-glucosidase is found in GH family 2. So far, glycoside hydrolases classified as $\mathrm{GH} 2$ were described to function as $\beta$-galactosidase

\footnotetext{
${ }^{1}$ http://www.cazy.org/
} 
(EC 3.2.1.23), $\beta$-mannosidase (EC 3.2.1.25), $\beta$-glucuronidase (EC 3.2.1.31), endo- $\beta$-mannosidase (EC 3.2.1.152), or as exo- $\beta$ glucosaminidase (EC 3.2.1.165). These enzymes hydrolyze their substrates through a retaining acid/base mechanism with two glutamic acid/glutamate residues involved. One residue acts as acid and base catalyst, whereas the other residue serves as nucleophile (Davies and Henrissat, 1995).

Glycoside hydrolases find a wide range of industrial applications. For instance, $\beta$-glucosidases are applied in biorefineries to reduce cellobiose-mediated product inhibition of endoglucanases. Thus, the addition of $\beta$-glucosidases leads to increased glucose concentrations during the enzymatic hydrolysis of cellulose, thereby increasing ethanol yields (Viikari et al., 2007). Furthermore, $\beta$-glucosidases and $\beta$-galactosidases are applied in the food industry to improve the aroma of juices and wine (Bhatia et al., 2002). Many industrial processes run at harsh conditions, e. g., elevated temperatures and extremes of $\mathrm{pH}$. Hence, the demand for novel enzymes which function at high temperatures or acidic or alkaline $\mathrm{pH}$ values is growing (Antranikian and Egorova, 2007).

Bacteria belonging to the genus Thermus grow at temperatures between 53 and $86^{\circ} \mathrm{C}$, and at $\mathrm{pH}$ values between 6.0 and 10.5 (Dworkin et al., 2006). Since the discovery of the type strain of this genus, Thermus aquaticus in 1969, numerous species have been isolated from hot environments (Brock and Freeze, 1969; Oshima and Imahori, 1974). Especially, the DNA polymerase from T. aquaticus (Taq DNA polymerase) became one of the key enzymes in molecular biology (Chien et al., 1976). Furthermore, thermostable DNA-processing enzymes such as ligases, helicases, or endonucleases have been identified (Pantazaki et al., 2002). Although Thermus spp. produce different hydrolytic enzymes like proteases or lipases, only few glycoside hydrolases have been characterized so far (Dion et al., 1999; Fridjonsson et al., 1999; Pantazaki et al., 2002; Kim et al., 2006; Nam et al., 2010; Blank et al., 2014).

In the current report, two genes coding for GHs (TaGH2 and $\mathrm{TbGH} 2$ ) were identified from Thermus antranikianii and Thermus brockianus. Conserved domains of GH2 were detected with incomplete motifs. The recombinant proteins showed highest activity toward 4-NP- $\beta$-D-glucopyranoside. The activity of $\mathrm{TaGH} 2$ toward cellobiose makes this enzyme unique when compared to the GH family 2 .

\section{Materials and Methods}

\section{Bacterial Strains and Plasmids}

Thermus antranikianii and Thermus brockianus were used as potential sources for the detection of $\beta$-glucosidase-encoding genes. Both strains were obtained from the collection of bacterial strains of the Institute of Technical Microbiology, Hamburg-Harburg. The strains Escherichia coli XL1-Blue MRF' $[\Delta(m c r \mathrm{~A}) 183 \Delta(m c r \mathrm{CB}-h s d \mathrm{SMR}-m r r) 173$ endA1 supE44 thi-1 recA1 gyrA96 relA1 lac [F' proAB lacIqZ $\Delta \mathrm{M} 15$ Tn10 $\left.\left.\left(\mathrm{Tet}^{\mathrm{R}}\right)\right]\right]$ and E. coli XLOLR $(\Delta(m c r A) 183 \Delta(m c r C B-h s d S M R-m r r) 173$ endA1 thi-1 recA1 gyrA96 relA1lac [F'proAB lacIqZ $\Delta \mathrm{M} 15$ $\left.\operatorname{Tn} 10\left(\mathrm{Tet}^{\mathrm{R}}\right)\right] \mathrm{Su}$-(non-suppressing) $\lambda \mathrm{r}$ ) were obtained from the “ZAP Express Predigested Vector Kit” (Agilent Technologies,
Waldbronn, Germany), and were utilized to construct and screen phagemid libraries using the vector $\mathrm{PBK}-\mathrm{CMV}$.

Escherichia coli Nova Blue Single ${ }^{\mathrm{TM}}$ (endA1 hsdR17( $\mathrm{r}^{-} \mathrm{K} 12$ $\left.\mathrm{m}^{+}{ }_{\mathrm{K} 12}\right)$ supE44 thi-1 recA1 gyrA96 relA1 lac $\mathrm{F}^{\prime}\left[\right.$ proA $^{+} \mathrm{B}^{+}$lacl ${ }^{\mathrm{q}}$ Z $\left.\Delta \mathrm{M} 15: \operatorname{Tn} 10\left(\mathrm{Tc}^{\mathrm{R}}\right)\right]$ ) (Novagen/Merck, Darmstadt, Germany) and $E$. coli $\mathrm{BL} 21 \mathrm{Star}^{\mathrm{TM}}(\mathrm{DE} 3)\left[\mathrm{F}^{-}\right.$omp $\mathrm{T} h s d \mathrm{SB}$ (rB-mB-) gal dcm rne131 (DE3)] (Invitrogen, Karlsruhe, Germany) were used as hosts for cloned PCR products and expression using the plasmids pJet1.2/blunt (Fermentas, St.Leon-Rot, Germany) and pQE-80L (Qiagen, Hilden, Germany).

\section{Media and Culture Conditions}

The Thermus strains were grown at $70^{\circ} \mathrm{C}$ and $200 \mathrm{rpm}$ for $16 \mathrm{~h}$ in Thermus 162 medium (DSMZ medium 878). E. coli strains were grown in LB medium at $30-37^{\circ} \mathrm{C}$ and $100-180 \mathrm{rpm}$ for $16 \mathrm{~h}$ (Sambrook et al., 2001). LB medium was supplemented with selected antibiotics (ampicillin: $100 \mu \mathrm{g} / \mathrm{mL}$, kanamycin: $50 \mu \mathrm{g} / \mathrm{mL}$ ) when cultivating bacteria harboring appropriate plasmids. For gene expression, isopropyl- $\beta$-D-thiogalactopyranoside (IPTG) in concentrations of $0.5-1.0 \mathrm{mM}$ were added.

\section{Isolation of DNA, Construction and Screening of Gene Libraries}

Genomic DNA from Thermus sp. was isolated according to the "Genomic DNA Handbook" (Qiagen, Hilden, Germany), and further purified by phenol/chloroform/isoamyl alcohol-extraction $(25 / 24 / 1)$ and ethanol precipitation. Plasmid DNA was isolated using the "GeneJET ${ }^{\mathrm{TM}}$ Plasmid Miniprep Kit" (Fermentas, St. Leon-Rot, Germany).

Isolated genomic DNA from Thermus strains was partially digested with BamHI to generate fragments of $5-10 \mathrm{~kb}$. DNA fragments of the desired size were separated by agarose gel electrophoresis. To prepare an agarose gel of $1 \%, 1 \mathrm{~g}$ agarose was dissolved in $100 \mathrm{~mL}$ TAE buffer ( $40 \mathrm{mM}$ Tris, $1 \mathrm{mM}$ EDTA, $40 \mathrm{mM}$ acetic acid, $\mathrm{pH}$ 8.5). The DNA was extracted from the gel by using the "GeneJet Gel Extraction Kit" (Fermentas, St. Leon-Rot, Germany). The ligation into the "ZAP Express Vector," as well as further steps for gene library construction were carried out according to the manufacturer's instructions.

To detect $\beta$-glucosidase-encoding genes, the gene libraries were plated on LB agar supplemented with $50 \mu \mathrm{g} / \mathrm{mL}$ kanamycin, and after growth over night the colonies were replicated on plates containing additionally $1 \mathrm{mM}$ IPTG. The clones were overlayed with buffer $\left(25 \mathrm{mM}\right.$ sodium acetate, $2.5 \mathrm{mM} \mathrm{CaCl}_{2} \times 2 \mathrm{H}_{2} \mathrm{O}, 170 \mathrm{mM}$ $\mathrm{NaCl}, 1 \%$ agarose, $\mathrm{pH} 6.5$ ) containing $2.5 \mathrm{mM}$ esculin and $0.4 \mathrm{mM}$ ammonium-iron(III)-citrate. After incubation at $70^{\circ} \mathrm{C}$ for $1-16 \mathrm{~h}$, $\beta$-glucosidase positive clones were observed by the formation of a brown halo around the colonies. E. coli XLOLR pBK-CMV clones displaying $\beta$-glucosidase activity were conserved as cryostocks containing $25 \%$ glycerol.

\section{Sequencing and Sequence Analysis}

Plasmids were isolated (“GeneJET ${ }^{\mathrm{TM}}$ Plasmid Miniprep Kit”, Fermentas, St. Leon-Rot, Germany) from selected clones, which conferred $\beta$-glucosidase activity. To determine the DNA-sequence of integrated DNA-fragments, the plasmids were sent to Eurofins MWG Operon (Ebersberg, Germany) for sequencing. 
Putative open reading frames (ORF) were detected using the program "FramePlot 4.0beta." 2 The DNA- and amino acidsequences were compared to the database of the "National Centre for Biotechnology Information" ( $\left.\mathrm{NCBI}^{3}\right)$ using the "Basic Local Alignment Search Tool” (BLAST) (Altschul et al., 1997). Conserved domains were predicted using "InterProScan" (EMBL$\mathrm{EBI}^{4}$ ) and the Conserved Domain Database (Marchler-Bauer et al., 2013). Glycoside hydrolase family 2 signatures were retrieved from http://prosite.expasy.org/PDOC00531. For multiple sequence alignments, ClustalW2 was employed (EMBL$\left.\mathrm{EBI}^{5}, 2013\right)$. Hypothetical models of protein structures, based on sequence homologies, were prepared with the program "SWISSMODEL" (Gasteiger et al., 2003).

\section{Cloning of Genes}

To amplify the $\beta$-glucosidase-encoding genes, specific primers were obtained from Eurofins MWG Operon (Ebersberg). For the amplification of the gene tagh2, the primers tagh2_f_PaeI ( $5^{\prime}$-GCATGCAGGTGGGAAAGAGCTTGGTTTTTG-3') and tagh2_r_SalIHindIII $\left(5^{\prime}\right.$-AAGCTTGTCGACTCACCAGGCCAC CCCCAGGG-3') were used, while tbgh_f (GGATCCAGGCTA AAAAGCGCCCTTTTC) and tbgh2_r (GTCGACCTACCAA GCCTCTCCAGG) were employed to amplify the gene $t b g h 2$.

The PCRs were carried out in a thermocycler according to the manufacturer's instructions. A mixture of $20 \mu \mathrm{L}$ contained $0.4 \mathrm{U}$ "Phusion High-Fidelity DNA-Polymerase" (Fermentas, St. Leon-Rot, Germany), 0.2 mM dATP, dCTP, dGTP, dTTP, $0.5 \mu \mathrm{M}$ of the forward and reverse primer, 10-300 ng template, reaction buffer, and distilled autoclaved water. The obtained PCR products were cloned into the pJet1.2/blunt vector (Fermentas, St. LeonRot, Germany), which was thereafter used to transform competent E. coli Nova Blue Single ${ }^{\mathrm{TM}}$ cells. Positive transformants were identified by colony PCR. Isolated pJet1.2/blunt plasmids were double digested with PaeI/SalI or BamHI/SalI to excise the $\beta$-glucosidase-encoding genes. The purified genes were ligated into the PaeI/SalI and BamHI/SalI digested expression vector pQE-80L, which was used to transform competent E. coli BL21 Star ${ }^{\mathrm{TM}}$ (DE3) cells. Positive transformants were identified by colony PCR and conserved as cryostocks containing 25\% glycerol.

\section{Production and Purification of the Enzymes}

E. coli BL21 Star ${ }^{\mathrm{TM}}$ (DE3) harboring the recombinant pQE80L plasmids were cultivated in $5 \mathrm{~mL}$ LB medium containing $100 \mu \mathrm{g} / \mathrm{mL}$ ampicillin at $37^{\circ} \mathrm{C}$ and $160 \mathrm{rpm}$ for $16 \mathrm{~h}$. The preculture was subcultivated in $500 \mathrm{~mL} \mathrm{LB}$ medium containing $100 \mu \mathrm{g} / \mathrm{mL}$ ampicillin until the culture reached an optical density of $\mathrm{A}_{600 \mathrm{~nm}}=0.5-0.7$. To induce protein production, $0.5 \mathrm{M}$ IPTG was added. The cultivation was continued for $6 \mathrm{~h}$, afterwards the cells were harvested by centrifugation at $13,000 \mathrm{rpm}$ for $20 \mathrm{~min}$ at $4^{\circ} \mathrm{C}$. The cell pellet was resuspended in lysis buffer (50 mM NaH $2 \mathrm{PO}_{4}, 300 \mathrm{mM} \mathrm{NaCl}, 10 \mathrm{mM}$ imidazole, $\mathrm{pH}$ 8) in the ratio $5 \mathrm{~mL}$ buffer/1 g pellet. Cells were disrupted by French press (French ${ }^{\mathrm{R}}$ Pressure Cell Press, SLM-Aminco, MD, USA).

\footnotetext{
${ }^{2}$ http://nocardia.nih.go.jp/fp4/

${ }^{3}$ http://www.ncbi.nlm.nih.gov/

${ }^{4}$ http://www.ebi.ac.uk/Tools/pfa/iprscan/

${ }^{5}$ http://www.ebi.ac.uk/Tools/msa/clustalw2/
}

Crude extracts with protein contents of $1.5 \mathrm{mg} / \mathrm{mL}$ ( $\mathrm{TaGH} 2)$ and $1.07 \mathrm{mg} / \mathrm{mL}(\mathrm{TbGH} 2)$ were obtained by centrifugation at $13,000 \mathrm{rpm}$ at $4^{\circ} \mathrm{C}$ for $20 \mathrm{~min}$.

For heat precipitation, the crude extract was incubated at $70^{\circ} \mathrm{C}$ for $15 \mathrm{~min}$, and subsequently centrifuged at $13,000 \mathrm{rpm}$ at $4^{\circ} \mathrm{C}$ for $20 \mathrm{~min}$.

As a second purification step, a $\mathrm{Ni}^{2+}$-nitrilic acid (Ni-NTA) affinity chromatography using a $1.5-\mathrm{mL}$ Ni-NTA superflow column (Qiagen, Hilden, Germany) was conducted. About $2-5 \mathrm{~mL}$ of the crude extract was incubated with $1 \mathrm{~mL}$ of Ni-NTA-agarose (Qiagen, Hilden, Germany) at $4^{\circ} \mathrm{C}$ and $200 \mathrm{rpm}$ for $1 \mathrm{~h}$. Two washing steps were performed $\left(50 \mathrm{mM} \mathrm{NaH}_{2} \mathrm{PO}_{4}, 300 \mathrm{mM} \mathrm{NaCl}\right.$, $25 \mathrm{mM}$ imidazole, $\mathrm{pH}$ 7.0). To elute the protein, six fractions of $500 \mu \mathrm{L}$ elution buffer $\left(50 \mathrm{mM} \mathrm{NaH}_{2} \mathrm{PO}_{4}, 300 \mathrm{mM} \mathrm{NaCl}, 250 \mathrm{mM}\right.$ imidazole, $\mathrm{pH}$ 7.0) were added to the column. Fractions containing the protein were pooled.

In the case of $T b \mathrm{GH} 2$, a gel filtration using the "ÄKTA ${ }^{\mathrm{TM}}$ Fast Protein Liquid Chromatography" (FPLC)-system (GE Healthcare, München, Germany) was carried out. One milliliter of the protein solution was load on a "HiLoad 16/60 Superdex 200 prep grade"column (GE Healthcare, München, Germany) with a flow rate of $1 \mathrm{~mL} / \mathrm{min}$. The protein was eluted with a 1.5 -fold column volume of $50 \mathrm{mM}$ sodium phosphate buffer, $\mathrm{pH} 7.2$, which contained $150 \mathrm{mM} \mathrm{NaCl}$. Enzyme fractions were pooled.

The purified proteins were dialyzed against $20 \mathrm{mM}$ citrate buffer $(\mathrm{TaGH} 2)$ or $20 \mathrm{mM}$ maleate buffer $(\mathrm{TbGH} 2)$ and stored at $4^{\circ} \mathrm{C}$.

The purity of the recombinant $\beta$-glucosidases was analyzed by sodium dodecyl sulfate polyacrylamide gel electrophoresis (SDSPAGE, 12\%) (Laemmli, 1970).

Protein concentrations were determined using the method described by Bradford (1976).

\section{Determination of Enzyme Activity}

Enzyme activity was determined by the released amounts of 2-nitrophenol (2-Np) and 4-nitrophenol (4-Np) from several nitrophenol-linked substrates (4-Np- $\beta$-D-glucopyranoside, 4 -Np- $\alpha$-D-glucopyranoside, 4 -Np- $\beta$-D-glucuronid, 4 -Np- $\beta$-Dgalactopyranoside, $2-\mathrm{Np}-\beta$-D-galactopyranoside, $\quad 4-\mathrm{Np}-\alpha-\mathrm{D}$ galactopyranoside, 4 -Np- $\beta$-D-xylopyranoside, 4 -Np- $\beta$-D-manno pyranoside, $4-\mathrm{Np}-\beta$-D-cellobioside).

The reaction mixture of $1 \mathrm{~mL}$ contained $2 \mathrm{mM} \mathrm{Np}$-substrate and $20 \mathrm{mM}$ citrate buffer $\mathrm{pH} 6.5(\mathrm{TaGH} 2)$, or $20 \mathrm{mM}$ maleate buffer $\mathrm{pH} 6.5(\mathrm{TbGH} 2)$. After preincubation of the reaction mixture for $5 \mathrm{~min}$ at $95^{\circ} \mathrm{C}(\mathrm{TaGH} 2)$ or $90^{\circ} \mathrm{C}(\mathrm{TbGH} 2), 10 \mu \mathrm{L}$ of diluted enzyme solution were added. The hydrolysis was stopped after $10 \mathrm{~min}$ by adding $100 \mu \mathrm{L}$ of $100 \mathrm{mM} \mathrm{Na} \mathrm{CO}_{3}$. The absorbance was measured at $410 \mathrm{~nm}$. All measurements were determined in triplicates. About $1 \mathrm{U}$ of enzyme activity was defined as the amount of enzyme needed for the release of $1 \mu \mathrm{mol} 4$-nitrophenol per minute. Kinetic parameters were determined according to Michaelis and Menten (1913).

\section{Effect of $\mathrm{pH}$ and Temperature}

Relative activities against 4 -Np- $\beta$-D-glucopyranoside $(2 \mathrm{mM})$ were measured in the range of $\mathrm{pH} 4.0-10.0$ using $20 \mathrm{mM}$ Britton-Robinson buffer (Britton and Robinson, 1931). To determine 
the $\mathrm{pH}$ stability, both enzymes were preincubated in $20 \mathrm{mM}$ Britton-Robinson buffer, $\mathrm{pH} 3.0-10.0$ at $4^{\circ} \mathrm{C}$ for $24 \mathrm{~h}$. To stabilize the enzymes, the concentration of the solution was adjusted to $0.1 \mathrm{mg} / \mathrm{mL}$ with BSA. After preincubation, the relative activity toward 4 -Np- $\beta$-D-glucopyranoside $(2 \mathrm{mM})$ was determined in $20 \mathrm{mM}$ Britton-Robinson buffer $\mathrm{pH} 6.5$ and $95^{\circ} \mathrm{C}(\mathrm{TaGH} 2)$, or in $20 \mathrm{mM}$ maleate buffer at $90^{\circ} \mathrm{C}(\mathrm{TbGH} 2)$.

The influence of temperature was determined by measuring relative enzyme activities in the range of $10-115^{\circ} \mathrm{C}$ with $4-\mathrm{Np}-\beta$ D-glucopyranoside $(2 \mathrm{mM})$ in $20 \mathrm{mM}$ citrate buffer $(\mathrm{TaGH} 2)$ or $20 \mathrm{mM}$ maleate buffer ( $\mathrm{TbGH} 2), \mathrm{pH}$ 6.5. To examine the temperature stability, both enzymes were preincubated at $50-90^{\circ} \mathrm{C}$ for $0-24 \mathrm{~h}$ in $20 \mathrm{mM}$ citrate buffer $(\mathrm{TaGH} 2)$ or $20 \mathrm{mM}$ maleate buffer (TbGH2), $\mathrm{pH}$ 6.5. The protein concentration of the solution was adjusted to $0.1 \mathrm{mg} / \mathrm{mL}$ with BSA. After preincubation, the relative activity toward $4-\mathrm{Np}-\beta$-D-glucopyranoside $(2 \mathrm{mM})$ was determined in $20 \mathrm{mM}$ citrate buffer $(\mathrm{TaGH} 2)$ or $20 \mathrm{mM}$ maleate buffer $(\mathrm{TbGH} 2), \mathrm{pH} 6.5$, at $95^{\circ} \mathrm{C}(\mathrm{TaGH} 2)$ and $90^{\circ} \mathrm{C}(\mathrm{TbGH} 2)$.

\section{Determination of Hydrolysis Products}

Hydrolysis products of $1 \%(\mathrm{w} / \mathrm{v})$ cellobiose and lactose were examined by HPLC (Agilent Technology 1260 Infinity Quarternary LC system with 1260 ALS sampler, 1260 Quat pump and $1260 \mathrm{R}_{\mathrm{i}}$ detector). The enzymes were incubated with the substrates at $90^{\circ} \mathrm{C}$ for $1 \mathrm{~h}$ in $20 \mathrm{mM}$ citrate buffer $(\mathrm{TaGH} 2)$ or $20 \mathrm{mM}$ maleate buffer ( $T b \mathrm{GH} 2$ ), $\mathrm{pH}$ 6.5. After hydrolysis, $20 \mu \mathrm{L}$ of the centrifuged and filtered solution was applied to a Hi-Plex H column (Agilent Technologies, Waldbronn, Germany). Water was used as solvent with a flowrate of $0.6 \mathrm{~mL} / \mathrm{min}$. To identify the hydrolysis products, the retention times $(\mathrm{min})$ were compared to the standards cellobiose (9.433), lactose (9.789), and glucose (11.247).

\section{Nucleotide Sequence Accession Number}

DNA sequences of tagh2 and tbgh2 were deposited in GenBank (tagh2: HG969993, tbgh2: HG969994).

\section{Results}

\section{Identification of Novel GH-Encoding Genes}

Gene libraries were constructed from pure cultures of $T$. antranikianii and T. brockianus, and screened for genes coding for enzymes active toward esculin. One activity-conferring E. coli clone was detected from each library. The respective inserts of the phagemids (pBK-CMV:Ta and pBK-CMV:Tb) harbored tagh2 and $t$ bgh 2 . The nucleotide sequences of tagh 2 and $t b g h 2$ were $80 \%$ identical. GC contents of 68.4 and $66.7 \%$ with GC proportions in the third codon position $\left(\mathrm{GC}_{3}\right)$ of 86.3 and $82.3 \%$ were observed.

The deduced amino acid sequences $\mathrm{TaGH} 2$ and $\mathrm{TbGH} 2$ possessed theoretical isoelectric points (pI) of $6.1(\mathrm{TaGH} 2)$ and 5.99 (TbGH2). Molecular masses of $79.0 \mathrm{kDa}(\mathrm{TaGH} 2)$ and $78.1 \mathrm{kDa}(\mathrm{TbGH} 2)$ were computed. The proteins were compared to proteins annotated in databases (GenBank). TaGH2 exhibited highest identity (98\%) to a putative $\beta$-galactosidase from Thermus scotoductus (YP_004203085, Table 1, Row 3). TbGH2 showed $82 \%$ identity to a hypothetical protein from Thermus $\mathrm{sp}$. (YP_005653839, Table 1, Row 4). The annotated proteins were deduced from ORFs identified in the course of whole genome sequencing projects of different Thermus species. Additionally, identities of $86 \%(\mathrm{TaGH} 2)$ and $83 \%(\mathrm{TbGH} 2)$ were obtained by comparison with a putative GH2 $\beta$-mannosidase from Thermus thermophilus (ACH89346, Table 1, Row 6). Identities to annotated proteins from Thermus sp. ranged from 83 to $98 \%$ $(\mathrm{TaGH} 2)$ and from 80 to $83 \%$ ( $\mathrm{TbGH} 2$ ). GH2 enzymes from genera other than Thermus were observed with identities of $38-42 \%$ (Caldilinea aerophila, YP_005442964 and Alicyclobacillus pohlia, WP_018133520.1; Table 1, Rows 7 and 8).

Notably, the Conserved Domain Database indicated two incomplete GH2 domains for both enzymes (Figure 1). A partial $\mathrm{GH} 2$ sugar-binding domain (pfam02837) in the protein sequence of TaGH2 (aa 23-93) and TbGH2 (aa 24-85), and an incomplete $\mathrm{GH} 2$ TIM-barrel domain (pfam02836) within TaGH2 (aa 298-410) and TbGH2 (aa 290-418) were predicted. Comparable domains were described for E. coli $\beta$-galactosidase LacZ in a complete form with low identities to the TIM-barrel domain ( $\leq$ $30 \%)$ and to the sugar-binding domain $(\leq 20 \%)$ of $\mathrm{TaGH} 2$ and TbGH2 (Figure 1). Within LacZ, the consensus patterns N-X-[LI VMFYWD]-R-[STACN](2)-H-Y-P-X(4)-[LIVMFYWS](2)-x(3)[DN]-X(2)-G-[LIVMFYW](4) and [DENQLF]-[KRVW]-N[HRY]-[STAPV]-[SAC]-[LIVMFS]-[LIVMFSA]-[LIVMFS]-W-

[GSV]-X(2,3)-N-E, which were described as conserved signatures of GH2, were identified ${ }^{6}$ (Figure 2). Principally, these conserved signatures were also detected as variations within $\mathrm{TaGH} 2$ and TbGH2.

${ }^{6} \mathrm{http}: / /$ prosite.expasy.org/PDOC00531

TABLE 1 | Identities of TaGH2 and TbGH2 to other GH2-proteins.

\begin{tabular}{|c|c|c|c|c|c|c|c|c|c|}
\hline & 1. & 2. & 3. & 4. & 5. & 6. & 7. & 8. & 9. \\
\hline 1. T. antranikianii $\mathrm{TaGH} 2$ & $100 \%$ & & & & & & & & \\
\hline 2. T. brockianus TbGH2 & $80 \%(100)$ & $100 \%$ & & & & & & & \\
\hline 3. T. scotoductus $\beta$-galactosidase (YP_004203085.1) & $98 \%(100)$ & $80 \%(100)$ & $100 \%$ & & & & & & \\
\hline 4. Thermus sp. hyp. Protein (YP_005653839.1) & $83 \%(100)$ & $82 \%(100)$ & $83 \%(100)$ & $100 \%$ & & & & & \\
\hline 5. T. igniterrae $\beta$-galactosidase (WP_018110934.1) & $82 \%(100)$ & $81 \%(100)$ & $81 \%(100)$ & $83 \%(100)$ & $100 \%$ & & & & \\
\hline 6. T. thermophilus put. $\beta$-mannosidase $(\mathrm{ACH} 89346.1)$ & $86 \%(92)$ & $83 \%(93)$ & $85 \%(99)$ & $84 \%(99)$ & $86 \%(87)$ & $100 \%$ & & & \\
\hline 7. A. pohliae put. Protein (WP_018133520.1) & $38 \%(97)$ & $41 \%(83)$ & $38 \%(90)$ & $38 \%(95)$ & $38 \%(94)$ & $41 \%(92)$ & $100 \%$ & & \\
\hline 8. C. aerophila put. GH (YP_005442964.1) & $41 \%(76)$ & $42 \%(82)$ & $41 \%(78)$ & $41 \%(84)$ & $42 \%(83)$ & $41 \%(96)$ & $45 \%(99)$ & $100 \%$ & \\
\hline 9. E. coli LacZ (1HN1_D) & $27 \%(35)$ & $29 \%(32)$ & $27 \%(37)$ & $27 \%(32)$ & $29 \%(46)$ & $28 \%(46)$ & $23 \%(61)$ & $23 \%(58)$ & $100 \%$ \\
\hline
\end{tabular}

Enzymes from Thermus spp. are highlighted in gray. Query-coverage values are indicated in \% in brackets.

Numbers at the top are listed in the left column. 


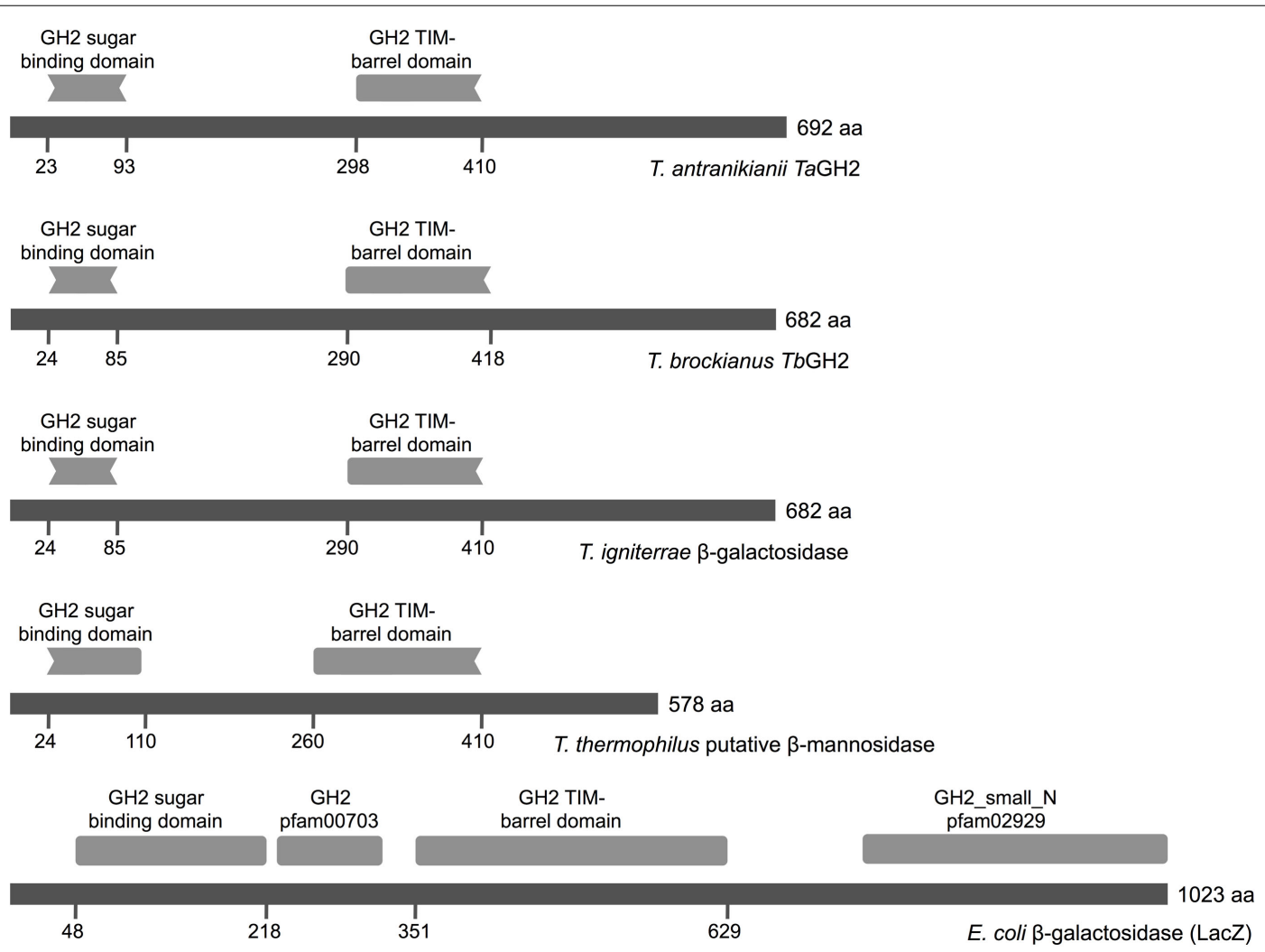

FIGURE 1 | Conserved domains of GH2 family enzymes. The amino acid sequences of TaGH2 (T. antranikianii), TbGH2 (T. brockianus), $\beta$-galactosidase (T. igniterrae, WP_018110934.1), putative $\beta$-mannosidase (T. thermophilus,
ACH89346), and LacZ (E. coli, 1HN1_D) are depicted in dark gray with homologous predicted sugar-binding domain (pfam02837) and TIM-barrel domain (pfam02836, Conserved Domain Database) in light gray.
PS00719 GH2 signature 1:

\begin{tabular}{|c|c|c|c|c|c|c|}
\hline TaGH2 & 316 & NAVR & ZVHAH & THPAFY & 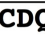 & GILVW \\
\hline TbGH2 & 308 & NAVR & VHAHI & THPVFY & CDF & VLVW \\
\hline $\mathrm{acz}$ & 384 & $\begin{array}{l}\text { NAVR } \\
\text { NXVR } \\
\end{array}$ & $\begin{array}{l}\text { CSHYP } \\
\text { CSHYP }\end{array}$ & $\begin{array}{l}\text { NHPLWY" } \\
\text { XXXXFY }\end{array}$ & & $\begin{array}{l}\text { GLYVV } \\
\text { GVIVW }\end{array}$ \\
\hline & & $\mathrm{L}$ & $\mathrm{TT}$ & LL & $\mathrm{N}$ & LVLL \\
\hline & & $I$ & $\mathrm{AA}$ & II & & IIII \\
\hline & & $\mathrm{M}$ & $\mathrm{SC}$ & MM & & MMMM \\
\hline & & $\mathrm{F}$ & NN & VV & & FFFF \\
\hline & & $Y$ & & $\mathrm{YF}$ & & YYYY \\
\hline & & W & & WW & & WWWT \\
\hline & & D & & SS & & \\
\hline
\end{tabular}

PS00808 GH2 signature 2:

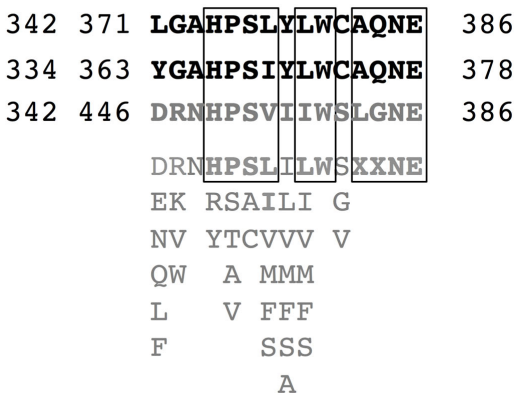

FIGURE 2 | Amino acid signatures of GH2 family enzymes. The amino acid sequences of $T a G H 2$ and $T b G H 2$ are shown in black and the sequence of LacZ (E. coli, 1HN1_D) and the consensus pattern of the two characteristic signatures of $\mathrm{GH} 2$ are depicted in gray with possible residue substitutions indicated below (http://prosite.expasy.org/PDOC00531). Corresponding amino acids are shown in bold characters and conformity within all sequences is framed.

\section{Expression of tagh2 and tbgh2 and Protein Purification}

The genes tagh2 and tbgh2 were amplified and expressed in E. coli BL21 Star ${ }^{\mathrm{TM}}$ (DE3) using pQE-80L (Figure 3). A high proportion of $\mathrm{TbGH} 2$ was produced in insoluble form. $\mathrm{TaGH} 2$ and $\mathrm{TbGH} 2$ were purified from soluble crude extracts. After heat precipitation and Ni-NTA affinity chromatography, TaGH2 was homogenous with a yield of $17.3 \%$, whereas $\mathrm{TbGH} 2$ was subsequently subjected to size exclusion chromatography with a yield of $6.7 \%$. The calculated molecular masses of $79.0 \mathrm{kDa}$ $(\mathrm{TaGH} 2)$ and $78.1 \mathrm{kDa}(\mathrm{TbGH} 2)$ were confirmed by SDS gel analysis (Figure 3). 

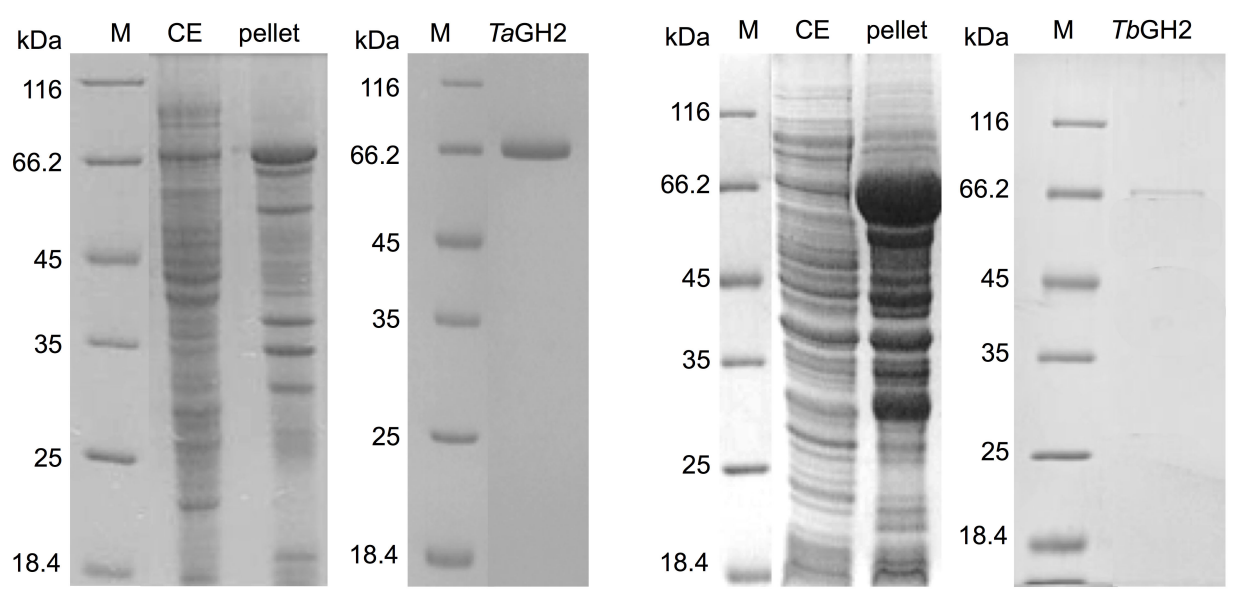

FIGURE 3 | SDS-PAGE analysis of crude extracts and purified TaGH2 and TbGH2. Soluble (CE) and insoluble (pellet) fractions of crude extracts and purified proteins were separated by SDS-PAGE (200 V, 50 min, M: Marker).

TABLE 2 | Kinetic parameters of TaGH2 and TbGH.

\begin{tabular}{|c|c|c|c|c|}
\hline & \multicolumn{2}{|c|}{$\begin{array}{l}\text { 4-Np- } \beta \text { - } \\
\text { glucopyranoside }\end{array}$} & \multicolumn{2}{|c|}{$\begin{array}{c}\text { 4-Np- } \beta- \\
\text { galactopyranoside }\end{array}$} \\
\hline & TaGH2 & TbGH2 & TaGH2 & TbGH2 \\
\hline$K_{\mathrm{m}}[\mathrm{mM}]$ & $0.73 \pm 0.03$ & $0.50 \pm 0.02$ & $2.20 \pm 0.02$ & $3.56 \pm 0.07$ \\
\hline $\begin{array}{l}V_{\max } \\
{\left[\mu \mathrm{mol} \min ^{-1} \mathrm{mg}^{-1}\right]}\end{array}$ & $4,028 \pm 21$ & $778 \pm 22$ & $2,615 \pm 3$ & $1,333 \pm 11$ \\
\hline$k_{\text {cat }}\left[\mathrm{s}^{-1}\right]$ & 21,559 & 3,899 & 13,996 & 6,683 \\
\hline$k_{\text {cat }} / K_{\mathrm{m}}\left[\mathrm{mM}^{-1} \mathrm{~s}^{-1}\right]$ & 29,532 & 7,797 & 6,361 & 1,877 \\
\hline
\end{tabular}

Activity of $\mathrm{TaGH} 2$ and $\mathrm{TbGH} 2$ was measured at $90^{\circ} \mathrm{C}$ in $20 \mathrm{mM}$ citrate or maleate buffer $(\mathrm{pH}$ 6.5) with $0-10 \mathrm{mM} 4-\mathrm{Np}-\beta-D$-glucopyranoside and $0-25 \mathrm{mM} 4-\mathrm{Np}-\beta-D-$ galactopyranoside for $10 \mathrm{~min}$

\section{Substrate Conversion and Kinetics of TaGH2 and TbGH2}

The purified enzymes $\mathrm{TaGH} 2$ and $\mathrm{TbGH} 2$ were analyzed regarding their substrate specificity. The predicted domains of GH2 and the highest homologies to annotated $\beta$-galactosidases suggested both enzymes being $\beta$-galactosidases. Nitrophenollinked substrates were tested and in contrast to expectations, $\mathrm{TaGH} 2$ and $\mathrm{TbGH} 2$ exhibited highest activities toward 4Np- $\beta$-D-glucopyranoside ( $\mathrm{TaGH} 2: 3,966 \mathrm{U} / \mathrm{mg}$ and $\mathrm{TbGH} 2$ : $660 \mathrm{U} / \mathrm{mg}$ ), and residual activities of 40 and $51 \%$ against 4Np- $\beta$-D-galactopyranoside. In accordance, Michaelis constants $\left(K_{\mathrm{m}}\right)$ were lower when 4 -Np- $\beta$-D-glucopyranoside was used as substrate (Table 2). The catalytic efficiency was $29,532 \mathrm{mM}^{-1} \mathrm{~s}^{-1}$ for $\mathrm{TaGH} 2$ and $7,797 \mathrm{mM}^{-1} \mathrm{~s}^{-1}$ for $\mathrm{TbGH} 2$. The maximum reaction rate $\left(V_{\max }\right)$ of $\mathrm{TaGH} 2$ was higher when measured with 4-Np- $\beta$-D-glucopyranoside $\quad\left(4,028 \pm 21 \mu \mathrm{mol} \quad \mathrm{min}^{-1} \mathrm{mg}^{-1}\right)$ compared to 4 -Np- $\beta$-D-galactopyranoside $\quad(2,615 \pm 3 \mu \mathrm{mol}$ $\mathrm{min}^{-1} \mathrm{mg}^{-1}$ ). On the contrary, $\mathrm{TbGH} 2$ exhibited a higher maximum reaction rate toward 4 -Np- $\beta$-D-galactopyranoside $\left(1,333 \pm 11 \mu \mathrm{mol} \mathrm{min}^{-1} \mathrm{mg}^{-1}\right)$ than toward 4-Np- $\beta$ D-glucopyranoside $\quad\left(778 \pm 22 \mu \mathrm{mol} \quad \mathrm{min}^{-1} \mathrm{mg}^{-1}\right)$. Other nitrophenol-linked substrates were not converted. Furthermore, non-nitrophenolic substrates, such as cellobiose and lactose
$(1 \%, \mathrm{w} / \mathrm{v})$, were tested. Interestingly, $\mathrm{TaGH} 2$ converted cellobiose (Figure 4). $\mathrm{TbGH} 2$ acted neither on cellobiose nor on lactose.

\section{Influence of Temperature and $\mathrm{pH}$}

Highest activities toward 4-Np- $\beta$-D-glucopyranoside were observed at $95^{\circ} \mathrm{C}(\mathrm{TaGH} 2)$ and $90^{\circ} \mathrm{C}(\mathrm{TbGH} 2)$ at $\mathrm{pH} 6.5$ (Figures 5 and 6). Residual activities of $83 \pm 2 \%(\mathrm{TaGH} 2)$ and $98 \pm 4 \%(\mathrm{TbGH} 2)$ were detected at $100^{\circ} \mathrm{C}$. $\mathrm{TaGH} 2$ showed no loss of activity when incubated at $50-90^{\circ} \mathrm{C}$ for $3 \mathrm{~h}$ (Table 3). By contrast, $\mathrm{TbGH} 2$ was less stable and showed $17 \pm 6 \%$ activity at $80^{\circ} \mathrm{C}$ after $3 \mathrm{~h}$ of incubation. At $70^{\circ} \mathrm{C}, \mathrm{TaGH} 2$ exhibited a half-life time of approximately $22 \mathrm{~h}$ and $\mathrm{TbGH} 2$ of $12 \mathrm{~h}$. In accordance, the predicted $T_{\mathrm{m}}$ was higher for $\mathrm{TaGH} 2\left(>65^{\circ} \mathrm{C}\right)$ when compared to $\mathrm{TbGH} 2\left(55-65^{\circ} \mathrm{C}\right)$ (Ku et al., 2009). Thermal activation was observed for both enzymes at 50 and $60^{\circ} \mathrm{C}$. The enzyme $\mathrm{TaGH} 2$ was stable when preincubated $\left(4^{\circ} \mathrm{C}, 24 \mathrm{~h}\right)$ at $\mathrm{pH}$ values between 3.0 and $10.0(81 \pm 5-100 \pm 2 \%)$. TbGH2 was stable at $\mathrm{pH}$ $3.5-7.5(71 \pm 8-114 \pm 13 \%)$ with residual activities of $63 \pm 7$ and $52 \pm 11 \%$ at higher $\mathrm{pH}$ values $(\mathrm{pH} 8.5,9.5)$.

\section{Influence of Additives}

The influence of different metal ions on the activity of $\mathrm{TaGH} 2$ and $\mathrm{TbGH} 2$ was tested (Table 4). $\mathrm{K}^{+}, \mathrm{Mg}^{2+}$, and $\mathrm{Na}^{+}$ions (1-10 mM) had no negative influence on the enzymatic performance of both enzymes. Furthermore, $\mathrm{Ca}^{2+}, \mathrm{Co}^{2+}, \mathrm{Mn}^{2+}, \mathrm{Ni}^{2+}$, $\mathrm{Rb}^{+}$, and $\mathrm{Sr}^{2+}(1-10 \mathrm{mM})$ had no significant influence on the hydrolytic action of $\mathrm{TaGH} 2(88 \pm 4-104 \pm 4 \%)$. The activity of $\mathrm{TbGH} 2$ was reduced in presence of $10 \mathrm{mM} \mathrm{CaCl} 2(56 \pm 20 \%)$, $\mathrm{MnCl}_{2}(64 \pm 12 \%), \mathrm{RbCl}(81 \pm 5 \%)$, and $\mathrm{SrCl}_{2}(67 \pm 15 \%)$, or completely inhibited in presence of $5-10 \mathrm{mM} \mathrm{CoCl}_{2}$ and $\mathrm{NiCl}_{2}$. TbGH2 was inactivated by $1 \mathrm{mM} \mathrm{Ag}^{+}, \mathrm{Cu}^{2+}$, and $\mathrm{Zn}^{2+}$. $\mathrm{TaGH} 2$ was exclusively inhibited by $\mathrm{Ag}^{+}$. $\mathrm{Fe}^{2+}$ and $\mathrm{Fe}^{3+}(1 \mathrm{mM})$ had no influence on the enzymatic performance of both hydrolases $(95 \pm 2-120 \pm 2 \%)$. TbGH2 showed higher activity when $1 \mathrm{mM} \mathrm{AlCl} 3(149 \pm 1 \%), \mathrm{CrCl}_{3}(139 \pm 4 \%), \mathrm{KCl}(146 \pm 4 \%)$, $\mathrm{MgCl}_{2}(136 \pm 4 \%), \mathrm{NaCl}(138 \pm 11 \%)$, or $\mathrm{RbCl}(143 \pm 10 \%)$ was added. 


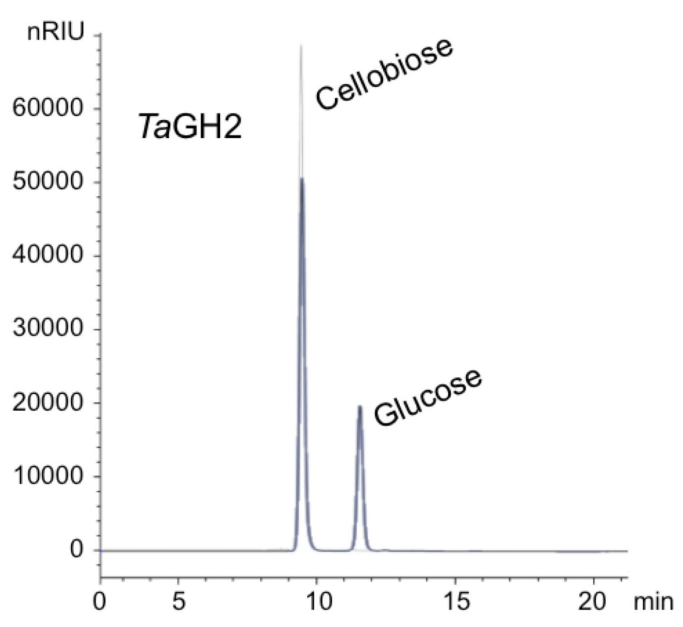

FIGURE 4 | HPLC analyses of cellobiose degradation. The degradation of cellobiose $(1 \% \mathrm{w} / \mathrm{v})$ by $\mathrm{TaGH} 2$ and by $\mathrm{TbGH} 2$ is depicted. The hydrolysis was carried out at $90^{\circ} \mathrm{C}$ for $1 \mathrm{~h}$ in $20 \mathrm{mM}$ citrate or maleate buffer $(\mathrm{pH} 6.5)$.

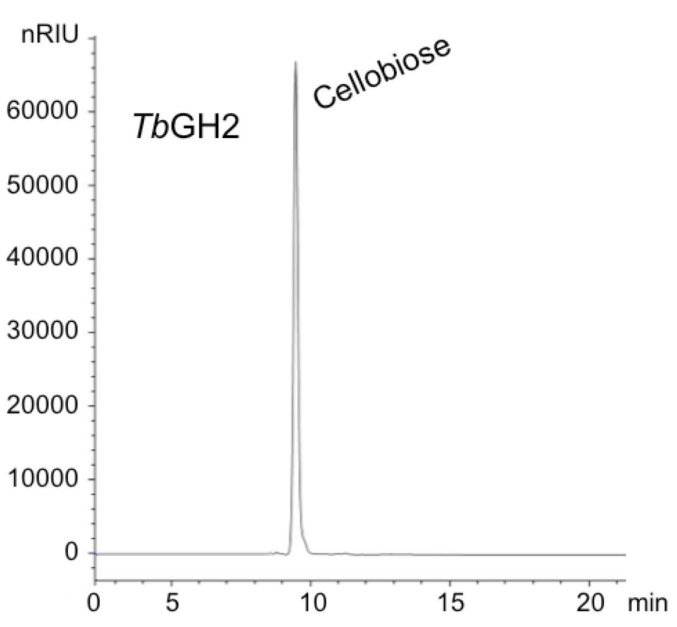

Subsequently, the samples were subjected to HPLC analyses using an Hi-Plex $\mathrm{H}$ column and water with a flow rate of $0.6 \mathrm{~mL} / \mathrm{min}$. Standards are shown in gray. nRIU, nano Refractive Index Units.

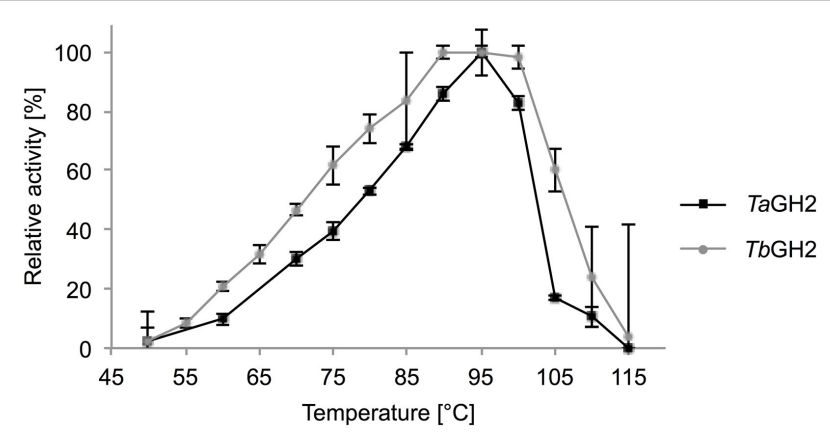

FIGURE 5 | Effect of temperature on activity of TaGH2 and TbGH2. Activity of $\mathrm{TaGH} 2$ and $\mathrm{TbGH} 2$ was measured at different temperatures $\left(50-115^{\circ} \mathrm{C}\right)$ for $10 \mathrm{~min}$ in $20 \mathrm{mM}$ citrate or maleate buffer (pH 6.5) with $2 \mathrm{mM}$ $4-\mathrm{Np}-\beta$-D-glucopyranoside. Temperatures above $95^{\circ} \mathrm{C}$ were measured in heated oil.

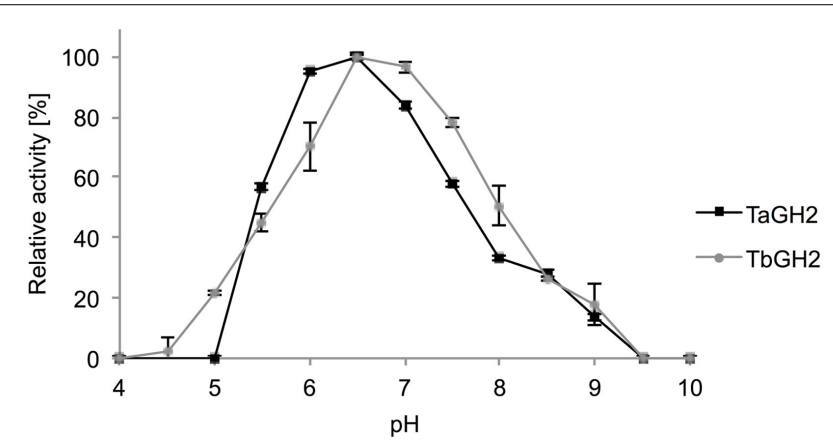

FIGURE 6 | Effect of pH on activity of TaGH2 and TbGH2. Activity of $\mathrm{TaGH} 2$ and $\mathrm{TbGH} 2$ was measured for $10 \mathrm{~min}$ at 95 or $90^{\circ} \mathrm{C}$ in $20 \mathrm{mM}$ Britton-Robinson buffer ( $\mathrm{pH} 4-10)$ with $2 \mathrm{mM} 4-\mathrm{Np}-\beta-\mathrm{D}-$ glucopyranoside.

The presence of $5 \mathrm{mM}$ additives, such as $\beta$-mercaptoethanol, DTT, EDTA, urea, iodoacetic acid, sodium azide, and Tween 80 did not decrease the activity of both enzymes. Moreover,
TABLE 3 | Effect of temperature on stability of TaGH2 and TbGH2.

\begin{tabular}{lccccc}
\hline & \multicolumn{2}{c}{ 3h } & \multicolumn{2}{c}{ 24h } \\
\cline { 2 - 3 } & TaGH2 & TbGH2 & & TaGH2 & TbGH2 \\
\cline { 5 - 6 } & $127 \pm 5$ & $129 \pm 9$ & $151 \pm 4$ & $246 \pm 12$ \\
$50^{\circ} \mathrm{C}$ & $123 \pm 2$ & $199 \pm 7$ & & $108 \pm 8$ & $202 \pm 10$ \\
$60^{\circ} \mathrm{C}$ & $123 \pm 4$ & $94 \pm 3$ & & $47 \pm 3$ & 0 \\
$70^{\circ} \mathrm{C}$ & $128 \pm 2$ & $17 \pm 6$ & $15 \pm 3$ & 0 \\
$80^{\circ} \mathrm{C}$ & $127 \pm 3$ & 0 & 0 & 0 \\
$90^{\circ} \mathrm{C}$ & & & &
\end{tabular}

Activity of $\mathrm{TaGH} 2$ and $\mathrm{TbGH} 2$ was measured at $90^{\circ} \mathrm{C}$ in $20 \mathrm{mM}$ citrate or maleate buffer (pH 6.5) with $2 \mathrm{mM} 4-\mathrm{Np}-\beta-D$-glucopyranoside for $10 \mathrm{~min}$ after preincubation for 3 or $24 \mathrm{~h}$, respectively, at different temperatures $\left(50-90^{\circ} \mathrm{C}\right)$. Activities determined at $0 \mathrm{~h}$ were set to $100 \%$.

Triton X-100 and Tween 20 did not influence the performance of $\mathrm{TbGH} 2$, whereas $\mathrm{TaGH} 2$ exhibited $49 \pm 2$ and $76 \pm 1 \%$ residual activity. Complete loss of activity for both glycoside hydrolases was detected when SDS or CTAB $(5 \mathrm{mM})$ were added.

\section{Discussion}

Screening of gene libraries from T. antranikianii and T. brockianus on esculin resulted in the identification of two novel glycoside hydrolases ( $\mathrm{TaGH} 2$ and $\mathrm{TbGH} 2$ ). Identities of amino acid sequences higher than $80 \%$ were observed to proteins from other Thermus species. The glycoside hydrolase family 2 domains (sugar binding domain and TIM-barrel domain) appeared to be incomplete. The domains are either truncated but functional or they are not recognized as domains due to large differences to other representatives of $\mathrm{GH} 2$. Comparison with the $\mathrm{GH} 2$ LacZ from E. coli (1HN1_D) showed low similarities within the corresponding domains. Additionally, conserved amino acid signatures typical for members of $\mathrm{GH} 2$ were partially identified (Figure 2). Similar hypothetical proteins with typical conserved domains from different genera were detected with identities of $39 \%(\mathrm{TaGH} 2)$ and $42 \%$ ( $\mathrm{TbGH} 2)$ or below. Thus, a differentiation of proteins produced from Thermus spp. would be suggested. 
TABLE 4 | Effects of metal ions on the activity of TaGH2 and TbGH2.

\begin{tabular}{|c|c|c|c|c|c|c|}
\hline \multirow[t]{2}{*}{ Reagent } & \multicolumn{3}{|c|}{ Relative activity of TaGH2 (\%) } & \multicolumn{3}{|c|}{ Relative activity of $\mathrm{TbGH} 2(\%)$} \\
\hline & $1 \mathrm{mM}$ & $5 \mathrm{mM}$ & $10 \mathrm{mM}$ & $1 \mathrm{mM}$ & $5 \mathrm{mM}$ & $10 \mathrm{mM}$ \\
\hline None & $100 \pm 3$ & $100 \pm 5$ & $100 \pm 2$ & $100 \pm 4$ & $100 \pm 4$ & $100 \pm 5$ \\
\hline $\mathrm{AgNO}_{3}$ & 0 & 0 & 0 & 0 & 0 & 0 \\
\hline $\mathrm{AlCl}_{3}$ & $97 \pm 4$ & $53 \pm 1$ & $17 \pm 5$ & $149 \pm 1$ & $98 \pm 13$ & 0 \\
\hline $\mathrm{CaCl}_{2}$ & $100 \pm 3$ & $100 \pm 4$ & $103 \pm 4$ & $93 \pm 6$ & $72 \pm 5$ & $56 \pm 20$ \\
\hline $\mathrm{CoCl}_{2}$ & $99 \pm 3$ & $101 \pm 2$ & $97 \pm 2$ & $52 \pm 7$ & 0 & 0 \\
\hline $\mathrm{CrCl}_{3}$ & $88 \pm 2$ & $43 \pm 3$ & $13 \pm 5$ & $139 \pm 4$ & $53 \pm 11$ & 0 \\
\hline $\mathrm{CuCl}_{2}$ & $98 \pm 4$ & $64 \pm 5$ & $20 \pm 4$ & 0 & 0 & 0 \\
\hline $\mathrm{FeCl}_{2}$ & $97 \pm 1$ & $42 \pm 3$ & 0 & $117 \pm 3$ & $31 \pm 14$ & 0 \\
\hline $\mathrm{FeCl}_{3}$ & $95 \pm 2$ & $53 \pm 4$ & $12 \pm 3$ & $120 \pm 2$ & $37 \pm 18$ & 0 \\
\hline $\mathrm{KCl}$ & $99 \pm 3$ & $98 \pm 3$ & $102 \pm 4$ & $146 \pm 4$ & $144 \pm 7$ & $83 \pm 5$ \\
\hline $\mathrm{MgCl}_{2}$ & $99 \pm 1$ & $103 \pm 2$ & $103 \pm 2$ & $136 \pm 4$ & $117 \pm 2$ & $113 \pm 7$ \\
\hline $\mathrm{MnCl}_{2}$ & $96 \pm 3$ & $98 \pm 1$ & $88 \pm 4$ & $94 \pm 15$ & $86 \pm 3$ & $64 \pm 12$ \\
\hline $\mathrm{NaCl}$ & $97 \pm 2$ & $99 \pm 4$ & $100 \pm 4$ & $138 \pm 11$ & $129 \pm 6$ & $104 \pm 10$ \\
\hline $\mathrm{NiCl}_{2}$ & $99 \pm 3$ & $104 \pm 4$ & $90 \pm 3$ & $61 \pm 13$ & 0 & 0 \\
\hline $\mathrm{RbCl}$ & $96 \pm 2$ & $102 \pm 1$ & $98 \pm 1$ & $143 \pm 10$ & $143 \pm 2$ & $81 \pm 5$ \\
\hline $\mathrm{SrCl}_{2}$ & $101 \pm 3$ & $104 \pm 4$ & $104 \pm 2$ & $127 \pm 4$ & $106 \pm 9$ & $67 \pm 15$ \\
\hline $\mathrm{ZnCl}_{2}$ & $99 \pm 2$ & $97 \pm 2$ & $64 \pm 3$ & 0 & 0 & 0 \\
\hline
\end{tabular}

Activity of TaGH2 and $\mathrm{TbGH} 2$ was measured at $90^{\circ} \mathrm{C}$ in $20 \mathrm{mM}$ citrate or maleate buffer (pH 6.5) with $2 \mathrm{mM} 4-\mathrm{Np}-\beta-D$-glucopyranoside for $10 \mathrm{~min}$ in presence or absence of metal ions.

Low sequence similarities within one protein superfamily could be the result of adaptation to different environmental conditions. Different enzymatic activities may have developed from a common ancestor (Galperin and Koonin, 2012). Structural diversification that preserved the active site residues may result in catalytically active enzymes with altered substrate specificity. Evolutionary pressure promotes functional and effective enzymes, which may result in reduction of conserved domains with remaining functionality (Juers et al., 1999). However, substrate specificity can be neglected for classification of glycoside hydrolases, since the structural homologies especially the motif forming the catalytic center is highly conserved (Henrissat and Davies, 1997). Homologies of up to 98 and $82 \%$, respectively, were observed by comparison with annotated $\beta$-galactosidases or $\beta$-mannosidases from Thermus species. No similar characterized enzyme to $\mathrm{TaGH} 2$ or $\mathrm{TbGH} 2$ was detected in the NCBI database; thus, classification of similar proteins was achieved by domain prediction rather than by functional analyses. Highest catalytic efficiencies for $\mathrm{TaGH} 2$ and $\mathrm{TbGH} 2$ were observed toward 4 -Np- $\beta$-D-glucopyranoside with residual activities toward 4$\mathrm{Np}-\beta$-D-galactopyranoside. Cellobiose conversion distinguishes $\mathrm{TaGH} 2$ from $\mathrm{TbGH} 2$. The hydrolysis characteristics may vary between artificial and natural substrates. This may be due to differences in size, charge, and binding properties of the artificial compound. Higher activity toward artificial substrates was also described as common phenomenon for $\alpha$-galactosidases (Wang et al., 2014). Hydrolysis of cellobiose or lactose by TbGH2 could not be detected, although high $\beta$-glucosidase activity was observed when the artificial substrate was used. $\beta$-Glucosidases are reported to often exhibit a broad substrate spectrum. A $\beta$-glucosidase from Thermotoga neapolitana hydrolyzed among others 4-Np- $\beta$-D-glucopyranoside, cellobiose, and lactose (Park et al., 2005). Likewise, a GH1- $\beta$-glucosidase derived from a hot-spring metagenome exhibited activity toward 4-Np- $\beta$-D-glucopyranoside, $\quad 4$-Np- $\beta$-D-galactopyranoside, cellobiose, and lactose (Schröder et al., 2014). However, the newly discovered $\mathrm{GH} 2 \beta$-glucosidases $\mathrm{TaGH} 2$ and $\mathrm{TbGH} 2$ showed a narrow substrate range.

Protein production in the mesophilic host E. coli resulted in notable amount of inclusion bodies due to differences in genomic GC contents of the genus Thermus, as previously reported (Ishida and Oshima, 1994; Fridjonsson et al., 1999). The $\beta$-glucosidase TaGH2 and the $\beta$-glucosidase/galactosidase TbGH2 showed high activities at elevated temperatures. Other $\beta$-glycosidases from Thermus thermophilus also show activity at $88-90^{\circ} \mathrm{C}$ and $\mathrm{pH}$ 5.4-7.0 (Dion et al., 1999; Nam et al., 2010). A thermal activation was detected at 50 and $60^{\circ} \mathrm{C}$, especially for $\mathrm{TbGH} 2$ with 246 and $202 \%$ activity after $24 \mathrm{~h}$, respectively. It was reported in the literature that enzymes from thermophilic organisms produced in mesophilic hosts may require thermal activation as demonstrated for a $\beta$-glycosidase from $T$. thermophilus at $70^{\circ} \mathrm{C}$ (Gerard et al., 2002). Specific activities were considered high with 3,966 and $660 \mathrm{U} / \mathrm{mg}$, when compared to the majority of previously reported $\beta$-glucosidases and $\beta$-galactosidases with $<1-100 \mathrm{U} / \mathrm{mg}^{7}$. Similar to GH family $1 \beta$-glycosidases from $T$. thermophilus, significantly lower $K_{\mathrm{m}}$ values were observed with 4 -Np- $\beta$-glucopyranoside when compared to -galactopyranoside (Dion et al., 1999; Nam et al., 2010). Highest substrate affinities for -glucopyranoside were also reported for other $\beta$-glucosidases from an uncultured soil bacterium and Cellulomonas flavigena with $K_{\mathrm{m}}$-values of 0.16 and $7.1 \mathrm{mM}$, respectively (Barrera-Islas et al., 2007; Kim et al., 2007). Hence, the enzymes described here exhibit $K_{\mathrm{m}}$-values in the range of other described GH1 $\beta$ glucosidases.

$\mathrm{Ag}^{+}, \mathrm{Cu}^{2+}$, and $\mathrm{Fe}^{3+}$ are most frequently described as glycoside hydrolase inhibitor (Cairns and Esen, 2010). By contrast, $\mathrm{Fe}^{3+}(1 \mathrm{mM})$ had no influence on the activity of both enzymes. Zinc ions inhibited $\mathrm{TbGH} 2$ completely but had, interestingly, no effect on activity of $\mathrm{TaGH} 2$. The surfactant CTAB $(5 \mathrm{mM})$ inhibited both enzymes. The negatively charged catalytic amino acids in the active center might be covered by the positively charged additive. Moreover, negatively charged surface residues might be influenced resulting in structural destabilization of the enzyme. Although three cysteins are present in the amino acid sequence of both enzymes, reducing agents such as DTT and $\beta$ mercaptoethanol did not show a negative effect on the activity. Either no disulfide bond is formed or it is not affected by the prevalent conditions. It is a frequently described phenomenon that reducing agents can also have stabilizing effects on enzymes (Park et al., 2005). The influence of additives on $\beta$-glucosidases and $\beta$ galactosidases does not follow a certain pattern, and appears to be specific for each individual enzyme.

$\mathrm{TaGH} 2$ and $\mathrm{TbGH} 2$ were classified as members of glycoside hydrolase family 2 based on amino acid sequence similarities. Although GH family 2 comprises enzymes with different substrate specificities, $\beta$-glucosidase activity has not been reported in this family, yet (Henrissat, 1991). This finding proves the necessity of function-based screening to identify genes coding for proteins with unusual domain structures or unexpected activities. The

${ }^{7}$ http://www.brenda-enzymes.org 
substrate specificity was reported to be less relevant than structural homologies for classification of members of glycoside hydrolase families (Henrissat and Davies, 1997).

In conclusion, our study demonstrates that enzymes structurally related to $\mathrm{GH}$ family 2 can exhibit more diverse substrate specificities than previously predicted. Therefore, we recommend to incorporate $\beta$-glucosidases into GH family 2 and consequently to evaluate activity on glucopyranosides including cellobiose for characterization of enzymes from this family.

\section{References}

Altschul, S. F., Madden, T. L., Schaffer, A. A., Zhang, J., Zhang, Z., Miller, W., et al. (1997). Gapped BLAST and PSI-BLAST: a new generation of protein database search programs. Nucleic Acids Res. 25, 3389-3402. doi:10.1093/nar/25.17.3389

Antranikian, G., and Egorova, K. (2007). "Extremophiles, a unique resource of biocatalysts for industrial biotechnlology," in Physiology and Biochemistry of Extremophiles, eds C. Gerday and N. Glansdorff (Washington, DC: ASM Press), 361-406. doi:10.1128/9781555815813.ch27

Barrera-Islas, G. A., Ramos-Valdivia, A. C., Salgado, L. M., and Ponce-Noyola, T. (2007). Characterization of a beta-glucosidase produced by a high-specific growth-rate mutant of Cellulomonas flavigena. Curr. Microbiol. 54, 266-270. doi:10.1007/s00284-006-0105-7

Bhatia, Y., Mishra, S., and Bisaria, V. S. (2002). Microbial beta-glucosidases: cloning, properties, and applications. Crit. Rev. Biotechnol. 22, 375-407. doi:10.1080/ 07388550290789568

Blank, S., Schröder, C., Schirrmacher, G., Reisinger, C., and Antranikian, G. (2014). Biochemical characterization of a recombinant xylanase from Thermus brockianus, suitable for biofuel production. JSM Biotechnol. Biomed. Eng. 2, 1027.

Bradford, M. M. (1976). A rapid and sensitive method for the quantitation of microgram quantities of protein utilizing the principle of protein-dye binding. Anal. Biochem. 72, 248-254. doi:10.1016/0003-2697(76)90527-3

Britton, H. T. S., and Robinson, R. A. (1931). Universal buffer solutions and the dissociation constant of veronal. J. Chem. Soc. 1456-1473. doi:10.1039/ jr9310001456

Brock, T. D., and Freeze, H. (1969). Thermus aquaticus gen. n. and sp. n., a nonsporulating extreme thermophile. J. Bacteriol. 98, 289-297.

Cairns, J. R., and Esen, A. (2010). $\beta$-Glucosidases. Cell. Mol. Life Sci. 67, 3389-3405. doi:10.1007/s00018-010-0399-2

Chien, A., Edgar, D. B., and Trela, J. M. (1976). Deoxyribonucleic acid polymerase from the extreme thermophile Thermus aquaticus. J. Bacteriol. 127, 1550-1557.

Davies, G., and Henrissat, B. (1995). Structures and mechanisms of glycosyl hydrolases. Structure 3, 853-859. doi:10.1016/S0969-2126(01)00220-9

Dion, M., Fourage, L., Hallet, J. N., and Colas, B. (1999). Cloning and expression of a beta-glycosidase gene from Thermus thermophilus. Sequence and biochemical characterization of the encoded enzyme. Glycoconj. J. 16, 27-37. doi:10.1023/A: 1006997602727

Dworkin, M., Falkow, S., Rosenberg, E., Schleifer, K. H., and Stackebrandt, E. (2006). The Prokaryotes. New York: Springer.

Fridjonsson, O., Watzlawick, H., Gehweiler, A., Rohrhirsch, T., and Mattes, R. (1999). Cloning of the gene encoding a novel thermostable alpha-galactosidase from Thermus brockianus ITI360. Appl. Environ. Microbiol. 65, 3955-3963.

Galperin, M. Y., and Koonin, E. V. (2012). Divergence and convergence in enzyme evolution. J. Biol. Chem. 287, 21-28. doi:10.1074/jbc.R111.241976

Gasteiger, E., Gattiker, A., Hoogland, C., Ivanyi, I., Appel, R. D., and Bairoch, A. (2003). ExPASy: the proteomics server for in-depth protein knowledge and analysis. Nucleic Acids Res. 31, 3784-3788. doi:10.1093/nar/gkg563

Gerard, F., Angelini, S., and Wu, L. F. (2002). Export of Thermus thermophilus cytoplasmic beta-glycosidase via the E. coli Tat pathway. J. Mol. Microbiol. Biotechnol. 4, 533-538.

Henrissat, B. (1991). A classification of glycosyl hydrolases based on amino acid sequence similarities. Biochem. J. 280(Pt 2), 309-316.

Henrissat, B., and Davies, G. (1997). Structural and sequence-based classification of glycoside hydrolases. Curr. Opin. Struct. Biol. 7, 637-644. doi:10.1016/ S0959-440X(97)80072-3

\section{Acknowledgments}

This work was supported by the German Federal Ministry of Education and Research (BMBF) in the funding cluster "Biorefinery2021," and by Clariant Produkte (Deutschland) $\mathrm{GmbH}$. This publication was supported by the German Research Foundation (DFG) and the Hamburg University of Technology (TUHH) in the funding program "Open Access Publishing". Thanks are also due to Bernard Henrissat for correspondence.

Ishida, M., and Oshima, T. (1994). Overexpression of genes of an extreme thermophile Thermus thermophilus, in Escherichia coli cells. J. Bacteriol. 176, $2767-2770$.

Juers, D. H., Huber, R. E., and Matthews, B. W. (1999). Structural comparisons of TIM barrel proteins suggest functional and evolutionary relationships between beta-galactosidase and other glycohydrolases. Protein Sci. 8, 122-136. doi:10. 1110/ps.8.1.122

Kim, D., Park, B. H., Jung, B. W., Kim, M., Hong, S., and Lee, D. (2006). Identification and molecular modeling of a family 5 endocellulase from Thermus caldophilus GK24, a cellulolytic strain of Thermus thermophilus. Int. J. Mol. Sci. 7, 571-589. doi:10.3390/i7120571

Kim, S. J., Lee, C. M., Kim, M. Y., Yeo, Y. S., Yoon, S. H., Kang, H. C., et al. (2007). Screening and characterization of an enzyme with betaglucosidase activity from environmental DNA. J. Microbiol. Biotechnol. 17, 905-912.

Ku, T., Lu, P., Chan, C., Wang, T., Lai, S., Lyu, P., et al. (2009). Predicting melting temperature directly from protein sequences. Comput. Biol. Chem. 33, 445-450. doi:10.1016/j.compbiolchem.2009.10.002

Laemmli, U. K. (1970). Cleavage of structural proteins during the assembly of the head of bacteriophage T4. Nature 227, 680-685. doi:10.1038/227680a0

Lombard, V., Golaconda Ramulu, H., Drula, E., Coutinho, P. M., and Henrissat, B. (2014). The carbohydrate-active enzymes database (CAZy) in 2013. Nucleic Acids Res. 42, D490-D495. doi:10.1093/nar/gkt1178

Marchler-Bauer, A., Zheng, C., Chitsaz, F., Derbyshire, M. K., Geer, L. Y., Geer, R. C., et al. (2013). CDD: conserved domains and protein three-dimensional structure. Nucleic Acids Res. 41, D348-D352. doi:10.1093/nar/gks1243

Michaelis, L., and Menten, M. L. (1913). Die Kinetik der Invertinwirkung. Biochem. Z. 49, 333-369.

Nam, E. S., Kim, M. S., Lee, H. B., and Ahn, J. K. (2010). $\beta$-Glycosidase of Thermus thermophilus KNOUC202: gene and biochemical properties of the enzyme expressed in Escherichia coli. Appl. Biochem. Microbiol. 46, 515-524. doi:10.1134/S0003683810050091

Oshima, T. I., and Imahori, K. (1974). Description of Thermus thermophilus (Yoshida and Oshima) comb. nov., a nonsporulating thermophilic bacterium from a Japanese thermal spa. Int. J. Syst. Bacteriol. 24, 102-112. doi:10.1099/ 00207713-24-1-102

Pantazaki, A., Pritsa, D., and Kyriakidis, A. (2002). Biotechnologically relevant enzymes from Thermus thermophilus. Appl. Microbiol. Biotechnol. 58, 1-12. doi:10.1007/s00253-001-0843-1

Park, T. H., Choi, K. W., Park, C. S., Lee, S. B., Kang, H. Y., Shon, K. J., et al. (2005). Substrate specificity and transglycosylation catalyzed by a thermostable beta-glucosidase from marine hyperthermophile Thermotoga neapolitana. Appl. Microbiol. Biotechnol. 69, 411-422. doi:10.1007/ s00253-005-0055-1

Sambrook, J., Fritsch, E., and Maniatis, T. (2001). Molecular Cloning, A Laboratory Manual, 3rd Edn. New York: Cold Spring Harbor Laboratory Press.

Schröder, C., Elleuche, S., Blank, S., and Antranikian, G. (2014). Characterization of a heat-active archaeal beta-glucosidase from a hydrothermal spring metagenome. Enzyme Microb. Technol. 57, 48-54. doi:10.1016/j.enzmictec.2014. 01.010

Viikari, L., Alapuranen, M., Puranen, T., Vehmaanpera, J., and Siika-Aho, M. (2007). Thermostable enzymes in lignocellulose hydrolysis. Adv. Biochem. Eng. Biotechnol. 108, 121-145. doi:10.1007/10_2007_065

Wang, H., Ma, R., Shi, P., Xue, X., Luo, H., Huang, H., et al. (2014). A new alphagalactosidase from thermoacidophilic alicyclobacillus sp. A4 with wide acceptor 
specificity for transglycosylation. Appl. Biochem. Biotechnol. 174, 328-338. doi:10.1007/s12010-014-1050-8

Conflict of Interest Statement: The authors declare that the research was conducted in the absence of any commercial or financial relationships that could be construed as a potential conflict of interest.
Copyright $\odot 2015$ Schröder, Blank and Antranikian. This is an open-access article distributed under the terms of the Creative Commons Attribution License (CC BY). The use, distribution or reproduction in other forums is permitted, provided the original author(s) or licensor are credited and that the original publication in this journal is cited, in accordance with accepted academic practice. No use, distribution or reproduction is permitted which does not comply with these terms. 